\title{
Comparative Karyotype and RAPD Analysis of Four Oxalis L. Species
}

\author{
Ishrat Jahan Bonna, Mahin Afroz, Syeda Sharmeen Sultana and \\ Sheikh Shamimul Alam*
}

Department of Botany, University of Dhaka, Dhaka-1000, Bangladesh

Received June 24, 2017; accepted August 3, 2017

\begin{abstract}
Summary Four Oxalis L. species namely $O$. corymbosa, O. corniculata, O. latifolia, and $O$. triangularis were investigated cytogenetically and at the molecular level for proper characterization. Different $2 n$ chromosome numbers were found in four species, such as $2 n=44$ in O. corniculata, $2 n=28$ in O. latifolia, $2 n=30$ in $O$. corymbosa, and $2 n=30$ in O. triangularis. The diploid chromosome number $2 n=30$ is the first report for $O$. triangularis. The four species differed with respect to centromeric formulae, such as $30 \mathrm{~m}$ in $O$. corymbosa, $44 \mathrm{~m}$ in $O$. corniculata, $24 \mathrm{~m}+4 \mathrm{sm}$ in O. latifolia, $26 \mathrm{~m}+4 \mathrm{sm}$ in O. triangularis. The four species of Oxalis have distinct CMA- and DAPI banding patterns based on the number, location, intensity, and percentage of GC- and AT-rich repeats. With the help of CMA and DAPI staining, it was possible to mark certain chromosomes specific for each species. Moreover, the four species possess distinct RAPD fingerprinting patterns with species-specific unique marker fragments. RAPD fingerprinting analysis placed $O$. corymbosa in a different cluster whereas the rest three in another cluster. Therefore, the compilation of the cytological and molecular information will be useful for authentic identification and characterization of the four Oxalis species found in Bangladesh.
\end{abstract}

Key words Fluorescent banding, Karyotype, RAPD, Oxalis L.

The genus Oxalis L. belongs to Oxalidaceae consisting of seven genera and about 900 species, mostly pantropical, the greater number of which is distributed in the warmer parts of the world (Rendle 1952, Mathew 1958). In Bangladesh, a wide range of occurrence of different Oxalis spp. is recorded (Ahmed et al. 2009). Among these species, Oxalis corniculata L. is a common herbaceous weed growing profusely with runners and extensively used as indigenous medicines for many diseases and as folklore remedy (Mohammad and Mir 2000). Other Oxalis spp. such as O. corymbosa DC., $O$. latifolia H.B.K., and O. triangularis A.St.-Hil. are grown as potential ornamental herbs because of their brilliant pink, white, and purple flowers and beautiful foliage (Mathew 1958, Sharma and Chatterji 1960, Ahmed et al. 2009).

Oxalis is a multibasic genus with fairly wide range of basic chromosome numbers. From the cytological data so far available it may be seen that $x=5,6,7,9$, and 11 are the existing basic chromosome numbers in the genus Oxalis, of which seven is the most frequently occurring number (Kumar and Subramaniam 1986, Marks 1956, Warburg 1938, Nakajima 1936).

The variation in chromosome number indicated that numerical chromosomal aberration makes this genus interesting for chromosome study. Though the genus

\footnotetext{
*Corresponding author, e-mail: ssalam81@yahoo.com

DOI: $10.1508 /$ cytologia.82.527
}

provides matters of considerable cytological interest, no cytological information is available for the Oxalis species growing in Bangladesh. The study of karyotypes is especially necessary where such varying basic chromosome number have been recorded. Such studies not only provide clues to the derivation of one form from the other but help to characterize each species.

However, conventional karyotype analysis alone is unable to critically express the differences among different species when closely related species possess similar $2 n$ chromosomes numbers (Khatun and Alam 2010, Khatun et al. 2011). Minute structural changes viz. deletion, inversion, tandem duplication, reshuffling the repeats, etc. could not be possible to detect by conventional karyotype analysis. In such a case, a combination of modern cytogenetical and molecular techniques is necessary for comparative studies among different species.

Fluorescent chromosome banding is an excellent tool for karyotype analysis. It helps to provide information regarding the reshuffling of $\mathrm{GC}$ - and AT-rich repeats in the genome. In addition, chromosomal abnormality could also be detected by this method (Schweizer 1976, Alam and Kondo 1995, Kondo and Hizume 1982, Jessy et al. 2005, Islam and Alam 2011, Sultana et al. 2011, Akter et al. 2015, Hossain et al. 2016).

Moreover, DNA fingerprinting by RAPD is one of the molecular methods for characterizing species. It includes characterization of genetic variability, genome finger- 
printing, genome mapping, gene localization, analysis of genome evolution, population genetics, taxonomy, etc. (Williams et al. 1993).

Except $O$. corniculata, the other available species viz. O. corymbosa, O. latifolia, and O. triangularis are vegetatively propagated, as a result, the genetic diversity is gradually narrowing. The extreme medicinal and ornamental uses make this genus vulnerable and thus under threat. If it is not managed or conserved at this stage, the consequences would be worse. For proper conservation and management, a multidimensional genetic characterization of each species is essential. Therefore, in the present study, a combination of cytogenetical and molecular analysis was carried out for the first time to characterize four Oxalis species viz. O. corymbosa, $O$. corniculata, $O$. latifolia, and $O$. triangularis found in Bangladesh. The aims of this research were:

i. to make a full strength orcein-stained karyotype for each species,

ii. to compare the fluorescent banding pattern after staining with CMA- and DAPI- fluorochromes,

iii. to compare RAPD banding patterns, and

iv. to characterize each species with cytogenetical and molecular markers.

\section{Materials and methods}

Among four Oxalis L. spp., O. triangularis L. was collected from a nursery in Agargaon, Dhaka, Bangladesh and the other three spp. of Oxalis namely $O$. corymbosa DC., O. corniculata L., O. latifolia H.B.K. from the Botanical Garden, Department of Botany, University of Dhaka. These four species were identified by Professor Dr. Momtaz Begum, Prof. Salar Khan Herbarium, Department of Botany, University of Dhaka and maintained in the Botanic Garden, Department of Botany, University of Dhaka, Bangladesh (Table 1).

\section{Cytogenetical study}

Healthy roots were collected and pretreated with 8-hydroxyquinoline $(0.002 \mathrm{M})$ for $2.30 \mathrm{~h}$ at $20-25^{\circ} \mathrm{C}$ followed by $15 \mathrm{~min}$ fixation in $45 \%$ acetic acid at $4^{\circ} \mathrm{C}$. The pretreated RTs were hydrolyzed for $1 \mathrm{~min} 45$ (depending on thickness of root) at $60^{\circ} \mathrm{C}$ in a mixture of $1 \mathrm{~N} \mathrm{HCl}$ and $45 \%$ acetic-acid $(2: 1)$. The root tips were stained and squashed in 1\% aceto-orcein. For CMAand DAPI banding, Alam and Kondo's (1995) method was used with slight modification. After hydrolysing and dissecting, the materials were squashed with $45 \%$ acetic acid. The cover glasses were removed quickly on dry ice and allowed to air dry for at least $24 \mathrm{~h}$ before the study. The air-dried slides were first incubated in McIlvaine's buffer ( $\mathrm{pH}$ 7.0) for $30 \mathrm{~min}$ followed by Distamycin A $\left(0.1 \mathrm{mg} \mathrm{mL}^{-1}\right)$ treatment for $10 \mathrm{~min}$. The slides were rinsed mildly in McIlvaine's buffer supplemented with $\mathrm{MgSO}_{4}(5 \mathrm{mM})$ for $15 \mathrm{~m}$. One drop of CMA $\left(0.1 \mathrm{mg} \mathrm{mL}^{-1}\right)$ was added to the materials for $15 \mathrm{~min}$ in a humid chamber and then rinsed with McIlvaine's buffer with $\mathrm{MgSO}_{4}$ for $10 \mathrm{~min}$. Slides were mounted in 50\% glycerol and kept at $4{ }^{\circ} \mathrm{C}$ for overnight before observation. These were observed under Nikon (Eclipse 50i) fluorescent microscope with blue violet (BV) filter cassette. For DAPI-staining, after $24 \mathrm{~h}$ of air drying, the slides were first incubated in Mcllvaine's buffer $(\mathrm{pH}$ 7.0) for $27 \mathrm{~min}$ and treated in Actinomycin $\mathrm{D}\left(0.25 \mathrm{mg} \mathrm{mL}^{-1}\right)$ for $10 \mathrm{~min}$ in a humid chamber. The slides were immersed in DAPI solution $\left(0.01 \mathrm{mg} \mathrm{mL}^{-1}\right)$ for $20 \mathrm{~min}$ and mounted with $50 \%$ glycerol. These were observed under a Nikon (Eclipse 50i) fluorescent microscope with ultra violet (UV) filter cassette.

\section{DNA isolation}

Leaves were harvested and total genomic DNA was extracted by using modified CTAB method (Doyle and Doyle 1987). DNA concentration was quantified through spectrophotometer (Analylikjena, Specord 50,

Table 1. Comparative phenotypes of four species of Oxalis L.

\begin{tabular}{|c|c|c|c|c|}
\hline \multirow{2}{*}{ Features } & \multicolumn{4}{|c|}{ Species } \\
\hline & O. corymbosa & O. corniculata & O. latifolia & O. triangularis \\
\hline 1. Stem & $\begin{array}{l}\text { A stemless herb produc- } \\
\text { ing tuberous rootstock with } \\
\text { brownish scales and radical } \\
\text { leaves }\end{array}$ & $\begin{array}{l}\text { A perennial herb with long, } \\
\text { slender, creeping stem, root- } \\
\text { ing at the nodes }\end{array}$ & $\begin{array}{l}\text { A stemless herb from bul- } \\
\text { bous base without rootstock } \\
\text { with scales and radical leaves }\end{array}$ & $\begin{array}{l}\text { A stemless herb from bul- } \\
\text { bous base without rootstock } \\
\text { with scales and radical leaves }\end{array}$ \\
\hline 2. Petiole & $5-18 \mathrm{~cm}$ long & $1-9 \mathrm{~cm}$ long & $18-22 \mathrm{~cm}$ long & $25-30 \mathrm{~cm}$ long \\
\hline 3. Leaf & $\begin{array}{l}\text { Green in color, palmately } \\
3 \text {-foliate }\end{array}$ & $\begin{array}{l}\text { Green in color, palmately } \\
\text { 3-foliate, comparatively } \\
\text { small in size }\end{array}$ & $\begin{array}{l}\text { Green in upper side and } \\
\text { purplish at lower side, pal- } \\
\text { mately, broadly obdeltoid, } \\
\text { 3-foliate }\end{array}$ & $\begin{array}{l}\text { Purple in color, palmately, } \\
\text { broadly obdeltoid, 3-foliate }\end{array}$ \\
\hline 4. Flower & $\begin{array}{l}\text { Pinkish purple in color, } \\
1.0-1.5 \mathrm{~cm} \text { long }\end{array}$ & $\begin{array}{l}\text { Yellow in color, } 0.4-0.5 \mathrm{~cm} \\
\text { long, comparatively small } \\
\text { in size }\end{array}$ & $\begin{array}{l}\text { White in color, } 1.25- \\
1.75 \mathrm{~cm} \text { long }\end{array}$ & $\begin{array}{l}\text { Pinkish white in color, } 1.0- \\
1.5 \mathrm{~cm} \text { long }\end{array}$ \\
\hline 5. Propagative organ & $\begin{array}{l}\text { Capsule not produced, Veg- } \\
\text { etatively propagated by tu- } \\
\text { bers }\end{array}$ & $\begin{array}{l}\text { Propagation by seeds and } \\
\text { stem cuttings }\end{array}$ & $\begin{array}{l}\text { Capsule not produced. Vege- } \\
\text { tatively propagated by fleshy } \\
\text { bulbs and bulbils }\end{array}$ & $\begin{array}{l}\text { Capsule not produced. Vege- } \\
\text { tatively propagated by fleshy } \\
\text { bulbs and bulbils }\end{array}$ \\
\hline
\end{tabular}


Germany). The A 260/280 readings for DNA samples were 1.6-1.8.

\section{PCR amplification and primer survey}

The PCR reaction mixture for $25 \mu \mathrm{L}$ containing template DNA $(25 \mathrm{ng}) 2 \mu \mathrm{L}$, de-ionized distilled water $18.8 \mu \mathrm{L}$, Taq buffer A $10 \times$ (Tris with $15 \mathrm{mMMgCl}_{2}$ ) $2.5 \mu \mathrm{L}$, primer $(10 \mu \mathrm{M}) 1.0 \mu \mathrm{L}$, dNTPs $(2.5 \mathrm{mM}) 0.5 \mu \mathrm{L}$ and Taq DNA polymerase $\left(5 \mathrm{U}_{\mu} \mathrm{L}^{-1}\right) 0.2 \mu \mathrm{L}$. PCR amplification was done in an oil-free thermal cycler (Biometra UNOII, Germany) for 46 cycles after initial denaturing $94^{\circ} \mathrm{C}$ for $5 \mathrm{~min}$, denaturing at $94^{\circ} \mathrm{C}$ for $1 \mathrm{~min}$, annealing at $34-36^{\circ} \mathrm{C}$ for $30 \mathrm{sec}$, extension at $72^{\circ} \mathrm{C}$ for $3 \mathrm{~min}$ and final extension at $72^{\circ} \mathrm{C}$ for $5 \mathrm{~min}$. Six random primers such as primer-21 (5'-GGCACTGAGG-3'), primer-23 (5'-GTC AGGGCAA-3'), primer-OPF-22 (5'-AAGATC AAA GAC-3'), primer-OPC-13 (5'-AAG CCT CGT C-3'), primer-OPC-14 (5'-TGC GTGCTT G$\left.3^{\prime}\right)$, and primer-OPC-26 (5'-CAC GTT ATC GCA-3') were used in the present study for screening.

\section{Gel electrophoresis}

The amplified products were separated electrophoretically on $1 \%$ agarose gel. The gel was prepared using $1.0 \mathrm{~g}$ agarose powder containing ethidium bromide $\left(10 \mathrm{mg} \mathrm{mL}^{-1}\right) 8 \mu \mathrm{L}$ and $100 \mathrm{~mL} 1 \times$ TAE buffer. Agarose gel electrophoresis was conducted in $1 \times \mathrm{TAE}$ buffer at $50 \mathrm{~V}$ and $100 \mathrm{~mA}$ for $1.5 \mathrm{~h}$. DNA ladder $(1 \mathrm{~kb})$ was electrophoresed alongside the RAPD reactions as marker. DNA bands were observed on UV-transilluminator and photographed by a gel documentation system.

\section{Scoring and data analysis}

The PCR products were analyzed after gel electrophoresis. The photographs were critically discussed on the basis of presence (1) or absence (0) of bands, size of bands, and overall polymorphism of bands. These were carried out for further investigation. The scores obtained using all primers in the RAPD analysis were then pooled for constructing a single data matrix. This was used for estimating polymorphic loci, Nei (1972) gene diversity, genetic distance (D), and constructing a UPGMA (Unweighted Pair Group Method of Arithmetic Means) dendrogram among the specimen using computer program "POPGENE" (Version 1.31).

\section{Results and discussion}

\section{Conventional karyotypes}

In this study, four Oxalis species showed different somatic chromosome counts such as $2 n=30$ in $O$. corymbosa and $O$. triangularis, $2 n=44$ in $O$. corniculata, and $2 n=28$ in O. latifolia (Figs. $1-4$, Table 2). The diploid chromosome number of $2 n=30$ for $O$. triangularis was determined in the present investigation. No chromosomal information of this species is available in the internet sources and relevant literature. Therefore, $2 n=30$ chromosomes is the first report for $O$. triangularis (Fig. 4).

In $O$. corymbosa, besides $2 n=30$ chromosomes, different chromosome numbers were reported earlier by different scientists viz. $2 n=22$ (Chatterjee and Sharma 1970), $2 n=28$ (Chatterjee and Sharma 1970, Chaudhuri et al. 1969), $2 n=30$ (Chatterjee and Sharma 1970), $2 n=42$ (Kumar and Subramaniam 1986). Thus the present report of $2 n=30$ chromosomes for $O$. corymbosa only correlates to that of Chatterjee and Sharma (1970). The presence of $2 n=30$ in $O$. corymbosa in this study made a confusion regarding the basic chromosome number (Fig. 1). It indicated that the species has either pentaploid or hexaploid nature with $x=5$ or $x=6$, respectively. Since Kumar and Subramaniam (1986) reported $2 n=42$ for this species, $x=6$ is most likely the basic chromosome number for this species.

Oxalis corniculata was found to possess $2 n=44$ chromosomes in the present study (Fig. 2). The same chromosome number was reported earlier by Chaudhuri et al. (1969), Chatterjee and Sharma (1970), and Bir et al. (1980). In addition, different chromosome numbers such as $2 n=24$ (Rutland 1941, Heiser and Whitaker 1948), $2 n=28,2 n=42$ (Kumar and Subramaniam 1986) and $2 n=48$ (Marks 1956, Mathew 1958, Sharma and Chatterji 1960, Murin and Sheikh 1971) were also reported. If the basic chromosome number of this species is considered as $x=11$, then specimens with $2 n=44$ observed in this study could be regarded as tetraploid. On the other hand, if $x=7$ is considered for this species, $2 n=28$ and $2 n=42$ could be the tetraploid and hexaploid, respectively. However, $2 n=24$ and $2 n=48$ did not agree with the basic number of $x=11$ and $x=7$. In this case, $2 n=24$ and $2 n=48$ might have evolved from nearer ploidy level by aneuploid aberration.

In O. latifolia, $2 n=28$ chromosomes were observed in this research work (Fig. 3). The present finding regarding $2 n$ chromosome number supports that of Weller et al. (1976). Moreover, different $2 n$ chromosome numbers of this species were reported earlier such as $2 n=14$ (Weller et al. 1976), $2 n=24$ (Sarker et al. 1974), $2 n=26$ (Chaudhuri et al. 1969, Chatterjee and Sharma 1970), $2 n=42$ (Weller et al. 1976), and $2 n=46$ (Chatterjee and Sharma 1970). Now, if $x=7$ is considered for this species, $2 n=28$ and $2 n=42$ could be tetraploid and hexaploid, respectively. In this situation, $2 n=24$ and $2 n=46$ did not agree with the basic number of $x=7$. Therefore, $2 n=24$ and $2 n=46$ might have evolved from aneuploid change from nearer ploidy level.

Among the four Oxalis species, O. corymbosa, and O. corniculata were found to possess all metacentric chromosomes (Table 2). In these two species, the range of chromosomal length was insignificant i.e., the distance between small and large chromosomes was about $1.88 \mu \mathrm{m}$ in $O$. corymbosa and $2.47 \mu \mathrm{m}$ in $O$. corniculata 

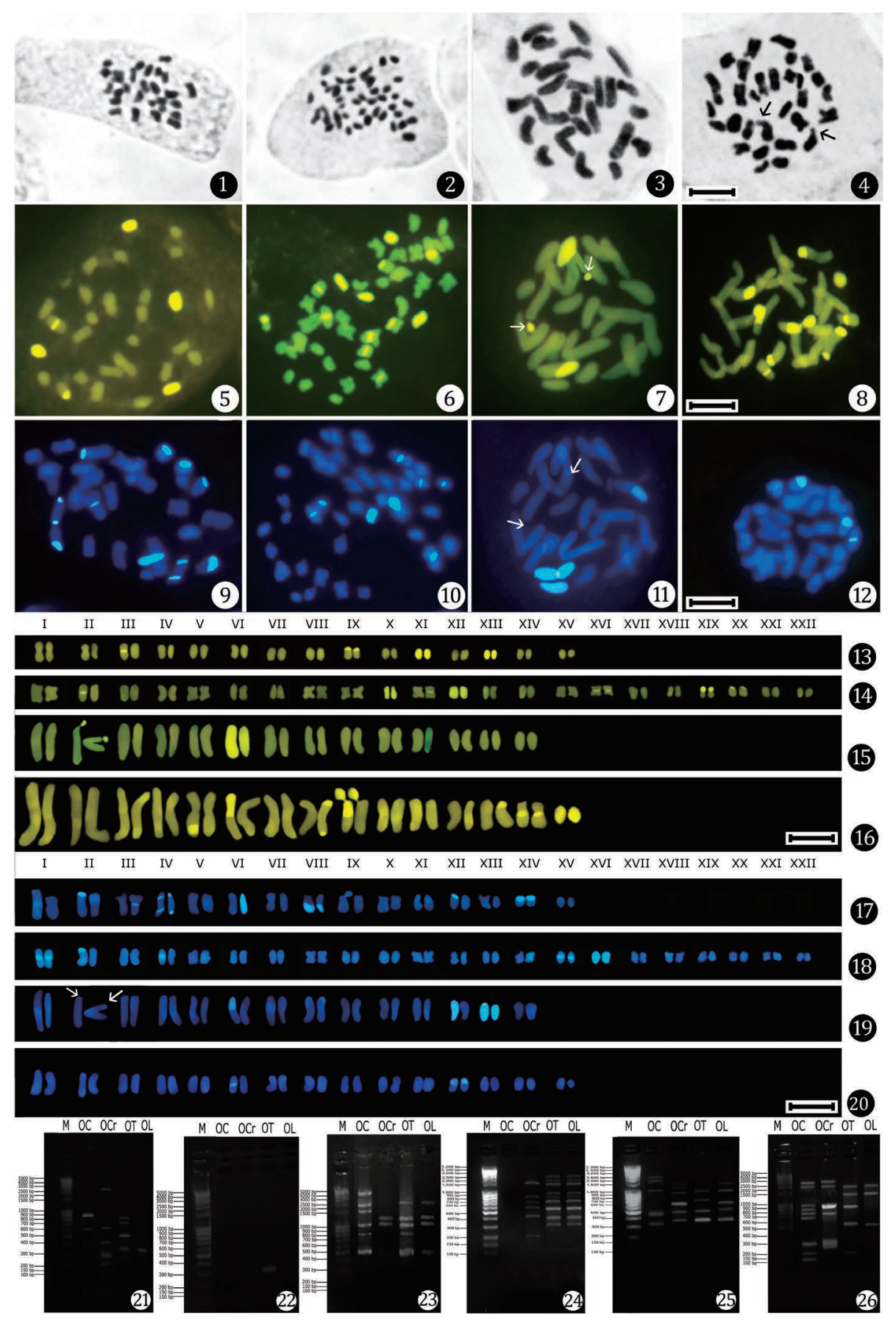

Figs. 1-26. Orcein-, CMA- and DAPI-stained mitotic metaphase and RAPD analysis of four species of Oxalis L. 1. Orceinstained mitotic metaphase chromosomes of $O$. corymbosa, 2. Orcein-stained mitotic metaphase chromosomes of $O$. corniculata, 3. Orcein-stained mitotic metaphase chromosomes of O. latifolia, 4. Orcein-stained mitotic metaphase chromosomes of O. triangularis, 5. CMA-stained mitotic metaphase chromosomes of O. corymbosa, 6 . CMA-stained mitotic metaphase chromosomes of $O$. corniculata, 7. CMA-stained mitotic metaphase chromosomes of $O$. latifolia, 8. CMA-stained mitotic metaphase chromosomes of $O$. triangularis, 9. DAPI-stained mitotic metaphase chromosomes of $O$. corymbosa, 10. DAPI-stained mitotic metaphase chromosomes of $O$. corniculata, 11 . DAPI-stained mitotic metaphase chromosomes of $O$. latifolia, 12. DAPI-stained mitotic metaphase chromosomes of $O$. triangularis, Bar $=10 \mu \mathrm{m}, 13$. CMA-karyotype of $O$. corymbosa, 14. CMA-karyotype of $O$. corniculata, 15 . CMA-karyotype of $O$. latifolia, 16. CMA-karyotype of $O$. triangularis, 17. DAPI-karyotype of O. corymbosa, 18. DAPI-karyotype of $O$. corniculata, 19. DAPI-karyotype of $O$. latifolia, 20. DAPI -karyotype of O. triangularis, Bar $=10 \mu \mathrm{m}, 21$. RAPD with primer-21, 22. RAPD with primer-23, 23. RAPD with primer-OPF-22, 24. RAPD with primer-OPC-13, 25. RAPD with primer-OPC-14. and 26. RAPD with primer-OPC-26.

(Table 2). As a result, no gradual decrease of chromosomal length was observed in their karyotypes (Table 2). These features indicated that these two species have strict symmetric karyotypes. However, in addition to maximum metacentric chromosomes, a few sub-metacentric chromosomes were observed in $O$. latifolia 
Table 2. Comparative orcein-, CMA- and DAPI- karyotype analysis of four species of Oxalis L.

\begin{tabular}{|c|c|c|c|c|c|c|c|c|c|}
\hline Oxalis species & $2 n$ & $\begin{array}{l}\text { Range of chromo- } \\
\text { somal length } \\
(\mu \mathrm{m})\end{array}$ & $\begin{array}{l}\text { Total length of } \\
2 n \text { chromosome } \\
\text { complement }(\mu \mathrm{m})\end{array}$ & $\begin{array}{l}\text { Centromeric } \\
\text { formulae }\end{array}$ & $\begin{array}{l}\text { No. of } \\
\text { CMA- } \\
\text { bands }\end{array}$ & $\begin{array}{l}\% \text { of } \\
\text { GC-rich } \\
\text { repeats }\end{array}$ & $\begin{array}{l}\text { No. of } \\
\text { DAPI- } \\
\text { bands }\end{array}$ & $\begin{array}{l}\% \text { of } \\
\text { AT-rich } \\
\text { repeats }\end{array}$ & $\begin{array}{c}\text { No. of } \\
\text { satellites }\end{array}$ \\
\hline O. corymbosa & 30 & $1.80-3.68$ & 79.11 & $30 \mathrm{~m}$ & 07 & 17.13 & 10 & 15.68 & 1 in DAPI \\
\hline O. corniculata & 44 & $1.56-4.03$ & 102.26 & $44 \mathrm{~m}$ & 12 & 20.36 & 08 & 11.59 & - \\
\hline O. latifolia & 28 & $4.72-9.27$ & 175.98 & $24 m+4 s m$ & 04 & 12.42 & 04 & 10.59 & 2 in $\mathrm{CMA}$ \\
\hline O. triangularis & 30 & $2.42-5.58$ & 127.62 & $26 m+4 s m$ & 11 & 29.29 & 03 & 3.78 & 2 in $\mathrm{CMA}$ \\
\hline
\end{tabular}

$\mathrm{m}=$ metacentric chromosomes, $\mathrm{sm}=$ sub-metacentric chromosome.

and $O$. triangularis. The sub-metacentric chromosomes might have originated from metacentric chromosomes by some chromosomal aberration viz. terminal deletion, pericentric inversion, non-reciprocal or unequal translocation. In these two species, the range of chromosomal length was significant i.e., distance between small and large chromosomes was $4.55 \mu \mathrm{m}$ in $O$. latifolia and $3.16 \mu \mathrm{m}$ in O. triangularis (Table 2). As a result, a gradual decrease of chromosomal length was observed in their karyotypes (Table 2). These features indicated that these two species have moderate asymmetric karyotypes. Stebbins (1971) mentioned that symmetric karyotypes were primitive and asymmetric karyotypes were advanced. Therefore, O. corymbosa and $O$. corniculata could be considered as relatively primitive species compared to the other two species.

\section{Fluorescent-banding}

The four Oxalis species used in this study differed sharply regarding the number, location, distribution, and intensities of CMA and DAPI-bands (Figs. 5-20, Table $2)$. It was observed that most of the banded chromosomes of the four species were entirely fluoresced with CMA and DAPI (Figs. 5-20, Table 2). Some chromosomes showed centromeric and a few terminal CMA and DAPI bands. In these entirely fluoresced chromosomes, GC- and AT-rich repeats were not confined but rather distributed along the chromosomes. The possible reason for these entirely fluoresced chromosomes was tandem amplification of GC- and AT-rich repeats (Schweizer 1976, Khatun and Alam 2010, Sultana and Alam 2007, Hiron et al. 2006, Mahbub and Alam 2007). Therefore, the chromosomes of Oxalis had a tendency for tandem duplication. The centromeric bands suggested no duplication of these repeats and confinement to a particular location. The origin of terminal bands might be due to paracentric inversion of banded portions from the centromere to the terminal ends.

\section{Stain specific satellite}

After CMA-staining, a pair of satellites was found in $O$. latifolia (on the short arm in each member of chromosome pair II) and in O. triangularis (on the short arm in each member of chromosome pair IX) (Figs. 15, 16). No satellite was found after orcein- and DAPI-staining in this pair of O. latifolia and O. triangulari (Figs. 19,
20). Moreover, in O. triangularis, a pair of satellites on the short arm in each member of chromosome pair $\mathrm{X}$ was observed after orcein-staining only (Fig. 4, arrow). In $O$. corymbosa, one satellite was observed in only a member of pair IX after DAPI staining (Fig. 17). Alam and Kondo (1995) reported about stain specific satellites in Drosera echinoblasta after a series of sequential staining with orcein, Giemsa, CMA, and DAPI. In the present study, the pair of satellites in $O$. corymbosa, $O$. latifolia, and $O$. triangularis might possess some kind of DNA sequence, which made these satellites stain-specific. However, no report about stain-specific satellites was available for different Oxalis species in earlier studies.

\section{Structural aberration in different Oxalis species}

Heteromorphicity with respect to banding patterns was observed in the four Oxalis species after CMAbanding. A centromeric CMA-positive band was observed in a member of pair III in $O$. corymbosa and pair II and XI in O. corniculata (Figs. 13, 14). No such band was found in their homologues. In addition, only one member of chromosome pair V, VI, IX, and XIII in $O$. triangularis showed CMA-positive bands on the entire short arm and long arm while their homologue members did not show any band (Fig. 16).

The four Oxalis species showed some heteromorphicity with respect to banding patterns after DAPI-staining as well. Only one member of chromosome pair II, III, VI, and XII in O. corymbosa, a member of chromosome pair II and IV in O. corniculata, a member of chromosome pair VI and XII in O. latifolia, and one member of chromosome pair VI in $O$. triangularis showed DAPIpositive bands at different regions while their homologue members did not show any band at the same location (Figs. 17-20). This heteromorphicity with respect to CMA- and DAPI-banding indicated the occurrence of deletion of the banded portions from the respective chromosomes.

Another type of heteromorphicity was found in chromosome pair IV in O. corymbosa with DAPI-staining. In this pair, one chromosome showed DAPI-positive bright bands at the interstitial regions of two arms whereas the other member had two dots like terminal DAPI bands (Figs. 9, 17). This kind of heteromorphicity indicated the occurrences of inversion between terminal and proximal portions of chromosomes (Zaman and 
Alam 2009).

A different kind of heteromorphicity was observed in Oxalis triangularis, where a member of chromosome pair VIII had terminal CMA-positive bands on both long arm and short arm (Figs. 8, 16). No band was found in its homologue. Sultana and Alam (2016) reported similar heteromorphicity in Gossypium hirsutum var. CB-11. They suggested the occurrence of unequal exchange of the banded region between the homologous chromosomes. The present results indicated such unequal crossing over between the members of a homologous pair in O. triangularis.

\section{RAPD analysis}

In this study, a total of 10 RAPD primers were applied on template DNA of four Oxalis species. Only six out of 10 primers were selected because they revealed multiband fingerprinting, which were easily scorable and reproducible. The primer sequences, band sizes, and banding patterns of four Oxalis species are shown in Table 3. The six primers generated a total of 96 distinct bands of which 28 were considered as unique bands. The term unique means that the sequence found in a specimen with a certain primer was absent in other specimens
(Figs. 21-26, Table 3). The unique bands were stable and specific for the respective species and thus could be used as a tool for characterization. In this study, 94.79\% polymorphism regarding RAPD banding patterns was recorded, which revealed the diverse nature of the four species. This result was supplemented by conventional and fluorescent karyotypic features because each species has distinct karyotype formula.

\section{Genetic distance and cluster analysis}

The dendogram based on RAPD markers showed that $O$. latifolia and $O$. triangularis are very close with a narrow genetic distance (Fig. 27). Morphologically, these two species are very close except their leaf and flower color (Table 1). These two species possess submetacentric chromosomes with higher $2 n$ chromosomal length and range of individual chromosome lengths. Moreover, lowest DAPI bands were found in these two species (Figs. 3-4, 11-12, 19-20, Table 2). Therefore, the molecular data is supplementing the karyotypic features of these two species.

The foregoing discussion revealed that the four Oxalis species have characteristic CMA-, DAPI-, and RAPDbanding patterns and therefore, could be characterized

Table 3. Compilation of RAPD analysis in four species of Oxalis L.

\begin{tabular}{|c|c|c|c|c|c|c|}
\hline Primer codes & Total bands & $\begin{array}{l}\text { Size ranges } \\
\text { (bp) }\end{array}$ & $\begin{array}{l}\text { Number of } \\
\text { common band }\end{array}$ & $\begin{array}{l}\text { Number of poly- } \\
\text { morphic band }\end{array}$ & $\begin{array}{c}\text { Number and size (bp) of } \\
\text { species specific unique bands }\end{array}$ & $\begin{array}{l}\text { Polymorphisms } \\
\text { (\%) }\end{array}$ \\
\hline Primer-21 & 12 & $200-2500$ & 0 & 12 & $\begin{array}{l}2(900,600 \mathrm{bp}) \text { in } O . \text { corymbosa, } 5(2500,630, \\
500,300,200 \mathrm{bp}) \text { in } O \text {. corniculata, } 4(800,700, \\
480,350 \mathrm{bp}) \text { in } O \text {. triangularis and } 1(320 \mathrm{bp}) \text { in } \\
\text { O. latifolia }\end{array}$ & 100.00 \\
\hline Primer-23 & 1 & 300 & 0 & 1 & $1(300 \mathrm{bp})$ in $O$. triangularis & 100.00 \\
\hline OPF-22 & 17 & $500-4000$ & 1 & 16 & $\begin{array}{l}4(4000,2000,1500,800 \mathrm{bp}) \text { in } O . \text { corymbosa and } \\
1(700 \mathrm{bp}) \text { in } O . \text { triangularis }\end{array}$ & 94.11 \\
\hline OPC-13 & 24 & $200-2500$ & 0 & 24 & $1(200 \mathrm{bp})$ in $O$. corniculata & 100.00 \\
\hline OPC-14 & 20 & $400-2500$ & 3 & 17 & $\begin{array}{l}2(2500,2000 \mathrm{bp}) \text { in } O . \text { corymbosa, } 2(1300, \\
650 \mathrm{bp}) \text { in } O . \text { corniculata, } 1(800 \mathrm{bp}) \text { in } O . \text { trian- } \\
\text { gularis and } 1(680 \mathrm{bp}) \text { in } O \text {. latifolia }\end{array}$ & 85.00 \\
\hline OPC-26 & 22 & $100-2800$ & 1 & 21 & $\begin{array}{l}2(900,100 \mathrm{bp}) \text { in } O \text {. corymbosa and }(500 \mathrm{bp}) \text { in } \\
\text { O. latifolia }\end{array}$ & 95.45 \\
\hline Grand Total: & 96 & $100-4000$ & 05 & 91 & 28 & 94.79 \\
\hline
\end{tabular}
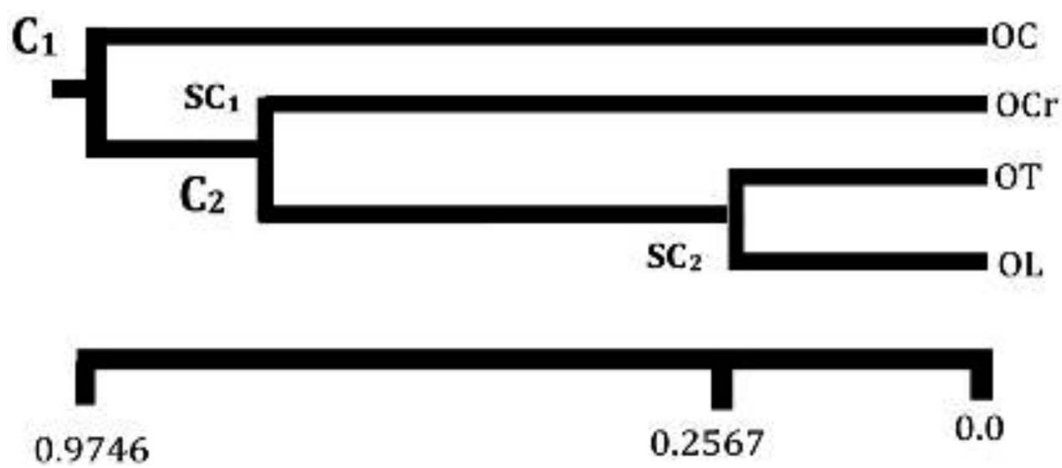

Fig. 27. UPGMA dendrogram based on Nei's (1972) genetic distance summarizing the data on differentiation between four species of Oxalis L. $\mathrm{M}=100 \mathrm{bp}$ DNA ladder. OC=Oxalis corymbosa $\mathrm{DC}$, $\mathrm{OCr}=$ Oxalis corniculata $\mathrm{L}$., OT=Oxalis triangularis A.St.-Hil and OL=Oxalis latifolia H.B.K. 
authentically with the help of combined cytogenetical and molecular data.

This research was partly supported by a grant from the Ministry of Science and Technology, People's Republic of Bangladesh and Chromosome Research Centre, University of Dhaka, Bangladesh.

\section{References}

Ahmed, Z. U., Begum, Z. N. T., Hassan, M. A., Khondker, M., Kabir, S. M. H., Ahmad, M., Ahmed, A. T. A., Rahman, A. K. A. and Haque, E. U. 2007. Encyclopedia of Flora and Fauna of Bangladesh, Angiosperms: Dicotyledons (Magnoliaceae-Punicaceae). Asiatic Society of Bangladesh, Dhaka. pp. 354-356.

Akter, L., Mahbub, M., Habib, M. A. and Alam, Sk. S. 2015. Characterization of three varieties of Lathyrus sativus $\mathrm{L}$. by fluorescent karyotype and RAPD analysis. Cytologia 80: 457-465.

Alam, Sk. S. and Kondo, K. 1995. Differential staining with Orcein, Giemsa, CMA, and DAPI for comparative chromosome study of 12 species of Australian Drosera (Droseraceae). Am. J. Bot. 82: 1278-1286.

Bir, S. S., Gill, B. S. and Kanta, S. 1980. In: Love, A. (ed.). Chromosome Number Reports LXIX. Taxon 29: 703-730.

Chatterjee, A. and Sharma, A. K. 1970. Chromosome study in Geraniales. Nucleus 13: 179-200.

Chaudhuri, R. K., Chatterjee, A. and Roy, S. C. 1969. New chromosome reports from plants of the Eastern Himalayas. In: Proceedings of the 56th Indian Science Congress, Bombay. p. 360.

Doyle, J. J. and Doyle, J. L. 1987. A rapid DNA isolation procedure from small quantities of fresh leaf tissues. Phytochem. Bull. 19: $11-15$.

Heiser, C. B. Jr. and Whitaker, T. W. 1948. Chromosome number, polyploidy, and growth habit in California weeds. Am. J. Bot. 35: 179-186.

Hiron, N., Alam, N., Ahmed, F. A., Begum, R. and Alam, Sk. S. 2006. Differential fluorescent banding and isozyme assay of Hibiscus canabinnas L. and H. sabdarffa L. (Malvaceae). Cytologia 71: 175-180.

Hossain, M. U., Islam, M., Afroz, M., Sultana, S. S. and Alam, Sk. S. 2016. Karyotype and RAPD analysis of male and female Coccinia grandis L. from Bangladesh. Cytologia 81: 349-355.

Islam, M. and Alam, Sk. S. 2011. Karyotype characterization with fluorescent banding in one released and two wild germplasms of Hibiscus cannabinus L. Cytologia 76: 223-227.

Jessy, N. S., Begum, R., Khatun, M. and Alam, Sk. S. 2005. Differential fluorescent chromosome banding of four species in Haworthia duval (Aloaceae). Cytologia 70: 435-440.

Khatun, M. and Alam, Sk. S. 2010. Confirmation of species status of Corchorus trilocularis by differential chromosome banding and isozyme assay. Cytologia 75: 83-88.

Khatun, M., Sultana, S. S., Ara, H., Islam, M. N. and Alam, Sk. S. 2011. Differential chromosome banding and isozyme assay of three Corchorus spp. Cytologia 76: 27-32.

Kondo, T. and Hizume, M. 1982. Banding for the chromosomes of Cryptomeria japonica D. Don. J. Japan For. Soc. 64: 356-358.

Kumar, V. and Subramaniam, B. 1986. Chromosome Atlas of Flowering Plants of the Indian Subcontinent. Dicotyledons. Botanical Survey of India, Kolkata.

Mahbub, M. N. and Alam, Sk. S. 2007. Karyotype comparison in two varieties of Vigna mungo L. after staining with orcein and CMA. Bangladesh J. Bot. 36: 167-170.

Marks, G. E. 1956. Chromosome numbers in the genus Oxalis. New Phytol. 55: 120-129.

Mathew, P. M. 1958. Cytology of Oxalidaceae. Cytologia 23: 200210.

Mohammad, I. S. and Mir, A. K. 2000. Folk use of medicinal herbs of Margalla Hills National Park, Islamabad. J. Ethnopharmacol. 69: $45-56$.

Murin, A. and Sheikh, M. Y. 1971. In: Love, A. (ed.). IOPB chromosome number reports XXXII. Taxon 20: 349-356.

Nakajima, G. 1936. Chromosome number in some crops and wild angiosperms. Jpn. J. Genet. 12: 211-217.

Nei, M. 1972. Genetic distance between populations. Am. Nat. 106: 283-292.

Rendle, A. B. 1952. The Classification of Flowering Plants, Vol. II. Cambridge University Press, Cambridge.

Rutland, J. P. 1941. The merton catalogue. New Phytol. 40: 210-214.

Sarker, A. K., Datta, N. and Chatterjee, U. 1974. In: Love, A. (ed.). IOPB chromosome number reports XLVI. Taxon 23: 801-812.

Schweizer, D. 1976. Reverse fluorescent chromosome banding with chromomycin and DAPI. Chromosoma 58: 307-324.

Sharma, A. K. and Chatterji, T. 1960. Cytological studies on three species of Oxalis. Caryologia 13: 755-765.

Stebbins, G. L. 1971. Chromosomal Evolution in Higher Plants. Addison-Wesley Publishing Company, Boston.

Sultana, S. S. and Alam, Sk. S. 2007. Differential fluorescent chromosome banding of Solanum nigrum L. and Solanum villosum L. from Bangladesh. Cytologia 72: 213-219.

Sultana, S. S. and Alam, Sk. S. 2016. Differential fluorescent banding in eleven varieties of Gossypium hirsutum L. from Bangladesh. Cytologia 81: 111-117.

Sultana, S. S., Ara, H. and Alam, Sk. S. 2011. Karyotype analysis with orcein and CMA in two species of Alocasia (Schott). G. Don. Banglad. J. Bot. 40: 53-56.

Warburg, E. F. 1938. Taxonomy and relationship in the Geraniales in the light of their cytology. New Phytol. 37: 189-210.

Weller, S. G. and Denton, M. F. 1976. Cytogeographic evidence for the evolution of distyly from tristyly in the North American species of Oxalis section Ionoxalis. Am. J. Bot. 63: 120-125.

Williams, J. G. K., Hanafey, M. K., Rafalski, J. A. and Tingey, S. V. 1993. Genetic analysis using random amplified polymorphic DNA markers. Methods Enzymol. 218: 704-740.

Zaman, M. Y. and Alam, Sk. S. 2009. Karyotype diversity in three cultivars of Momordica charantia L. Cytologia 74: 473-478. 